\title{
Members of the human body prone to musculoskeletal damages: a comparison between the sector of transportation and footwears production
}

\author{
Gomes de Lima, Jeane F. ${ }^{*}$, Colaço, Geraldo, da Silva, Ricardo and Masculo, Francisco \\ Department of Production Engineering, Federal University of Paraiba, PPGEP, João Pessoa, Paraíba, Brazil.
}

\begin{abstract}
This study present areas of the body more prone to develop diseases by musculoskeletal efforts, ie, RTD, in two companies of Paraiba, Brazil. To this end, was made a comparative analysis with respect to the type of work performed (standing, sitting) and the parts that suffer most discomfort after a day's work in a footwear industry and a bus transportation company. The quanti-qualitative research was conducted through semi-structured interviews with 227 employees in the period 2008 to 2009, having as methodological the tool diagram of painful areas of Corlett and Manenica. It was concluded that the areas most affected by musculoskeletal disorders are located in the neck $(9,2 \%)$, backs $(23,6 \%)$, shoulders $(14,5 \%)$ and legs $(11,3 \%)$, being usually caused by inapproprietes postures, repetitive movements and work station no adequate the anthropometry of the users. Thus, we recommend the adoption of ergonomic measures that enable a healthy and safe environment for workers.
\end{abstract}

Keywords: ergonomics; musculoskeletal diseases; industry; service

\section{Introduction}

To carry out its functions the workers can adopt the stand or seated posture, so that the man executes several different positions to develop his activities in the workplace. The activities accomplished by the employees in the transformation and services industries are constantly prone to work conditions that can bring diseases or musculoskeletal disorders in the users' workstation.

Data from the Social Security [1] show that in 2008 , in the work-related diseases, the body parts that suffered most incidents were the shoulder, the back (including back muscles, spine and spinal cord) and upper limbs (not informed) with 18.8\%, 12.3\% and $9.8 \%$ respectively.

So it is important to pay attention to the posture adopted to perform the activities. When done improperly they can overwhelm some of these regions of the body, predisposing it to future musculoskeletal diseases.

In recent years there has been a worrying growth of musculoskeletal disease related to work [13]. It is believed that technological change in organizations is one of the factors that contribute to this scenario.

If on a side, the technological innovations bring undeniable productivity conquests to the companies, on the other hand, they can reduce the industrial efficiency when they harm the health of the workers when demanding of these repetitive postures in the execution of the work. Besides still increasing the social and production costs [7].

One among many reasons is that, on the most part, of the production systems, the focus is only on the production itself, which can provide conditions of risk health to the user's of the workstation.

However, to refocus on the adoption of good ergonomic practices can enable the reduction of work disease and accidents, with increased in the satisfac-

*Corresponding author. E-mail: jeanegl@yahoo.com.br. 
tion employee and, consequently, improvement their quality of life. So, this study has for objective to present the parts of the human body that are prone to diseases due to muskuloskeletal effort, in the productive sector and of service in located companies in the state of Paraíba, Brazil.

\section{Musculoskeletal diseases}

The musculoskeletal diseases are one of the main health problems faced by workers today, may drive them to an inability to perform activities due to the repetitive use of movement or maintenance of awkward postures at work. The results of this are: pain, fatigue, muscle weakness, swelling and, consequently, work performance declining [14-15].

According to the Social Security [2], these diseases are the second leading cause of absenteeism in Brazil. Withdraw the employee's work is an important and essential for the treatment of musculoskeletal injuries because removes the worker of the risk factors: repetitive efforts without breaks, machinery and furniture that favor the use of inadequate postures, pressures, excess in the pace and on working hours, among others.

Thus, it is important that efforts be concentrated in order to prevent and identify musculoskeletal disorders according to the physical exigencies of each work $[3,9]$. Changes in muscle movements and posture to perform an activity help in the prevention and treatment of RTD, enabling better work performance [5].

But for these measures be practiced in world business is crucial have involvement of employees, of all hierarchical levels, regarding the actions related to health and safety worker, including policies and procedures well-defined, disseminated and circulated among the members of the organization.

\section{Occupational Safety and Health (OSH)}

For a long time issues related to Occupational Safety and Health (OSH) were treated superficially within companies. However, in today's environment of fierce competition that involves some organizations it is imperative that they be guided by rules, policies, programs and procedures related to maintaining a work environment healthy and safe.

There are a number of situations in the workplace that contribute to the increase in musculoskeletal disorders suffered by workers, some are: postural stress of the session standing prolonged or awkward position, repetitive tasks, environmental and psychosocial factors, job dissatisfaction, among others [11]. In this scenario, actions should be developed in order to identify and assess risks, as well as should be established and taken measures to prevent accidents in the workplace, ensuring the well-being mental and social workers.

However, according to the particularities of each company (eg type of work, organization of the processes and layouts, size, participation strategy) there will certainly be differences in implementation and evaluation of OSH measures [8]. Therefore, there isn't a formula that guarantees success in the implementation of standards and procedures relating to occupational safety and health. However, the adoption of these measures provides to employees, current and new, be trained and then perform their work safely, avoiding that the bad practices become part of everyday life [4].

Thus, the practice of principles aimed at $\mathrm{OSH}$ must go beyond legal obligations. It is essential to involve all company employees in the design and development of programs that provide the knowledge necessary to conduct their safely activities. How many greater employee participation, more easily will be identified and implemented ergonomic improvements in the company, ie, improvements in all sectors [10]. In return, must the organization to provide regularly reports and reports of actions taken and results to employees [12]. All these factors contribute to the creation and dissemination of a culture prevention in health and safety in the workplace.

\section{Method}

It was done a comparative study between the areas in which the workersof developed activities and the parts of the body in that the users indicated as more uncomfortable after a day of work of eight hours.

The research used the tool Corlett and Manenica (1980) and it was accomplished, in the period from 2008 to 2009,227 interviews in a company of transportation. $83 \%$ of the subjects where bus drivers and in the shoe industry, production operators $(17 \%$ of thew subjects of the research) they investigated.

It was used semi-structured interview with the employees of the workstations, being done later the quali-quantitative analysis of the data and the obtained reports. 


\section{Results}

This analysis helps to provide means of visualizing the activities and workplaces that can provide repetitive trauma disorders (RTD) in the segments of activities studied, as well as the members of the body that signal there to be larger propensity to muskuloskeletal diseases.

\subsection{Results by types of activities}

\section{Transportation}

The activity of driving bus is accomplished seated in every work day and the whole day.

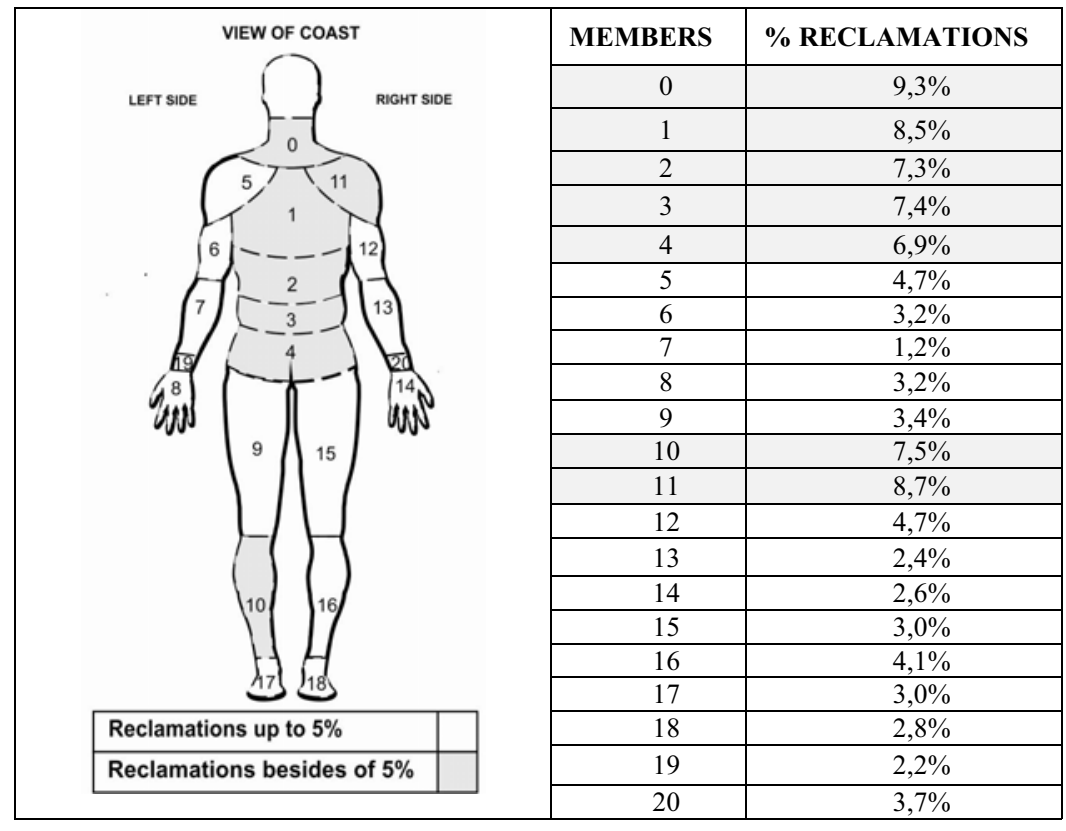

Figure 1. Part of the human body more lesioned - Transportations Source: Field research

The movements of to hold, to rotate and to pressure in the steering wheel, marches and the devices started by the feet done by the drivers bring discomfort in the areas of the body, mainly in the neck (0), backs $(1,2,3)$ and hip (4). 39,4\% of the lesion complaints or indisposition refer the those areas.

Due to the repetitive movement of working the clutch and the gear changes the left leg (10) and the right shoulder (11) were also pointed as parts that present discomfort by the end of the work day $-7,5 \%$ and $8,7 \%$ of the complaints, respectively.

The absence of maintenance of devices as the gear and steering wheel, for instance, presses the musculature of the shoulders, causing lesions to the workers. Besides, it was verified the difficulty of assisting the drivers' anthropometry in some workplaces, in other words, in some bus. Some seats, for instance, are not possible to be regulated, as result use the foot to start some devices need to reach it with difficulties by some employees. .

\section{Shoe Industry}

The activities accomplished in the shoe sector with respect to productive process are accomplished in standing position during the whole work day.

As it can be observed in the illustration 2, neck (0), back $(1,2,3)$, shoulders $(5,11)$, arm and left hand $(6$, 8 - respectively) and wrists $(19,20)$ are the areas more damaged, according to the employees of this segment.

\begin{tabular}{|l|l|l|}
\hline VIEW OF COAST & MEMBERS & \% RECLAMATIONS \\
\hline
\end{tabular}




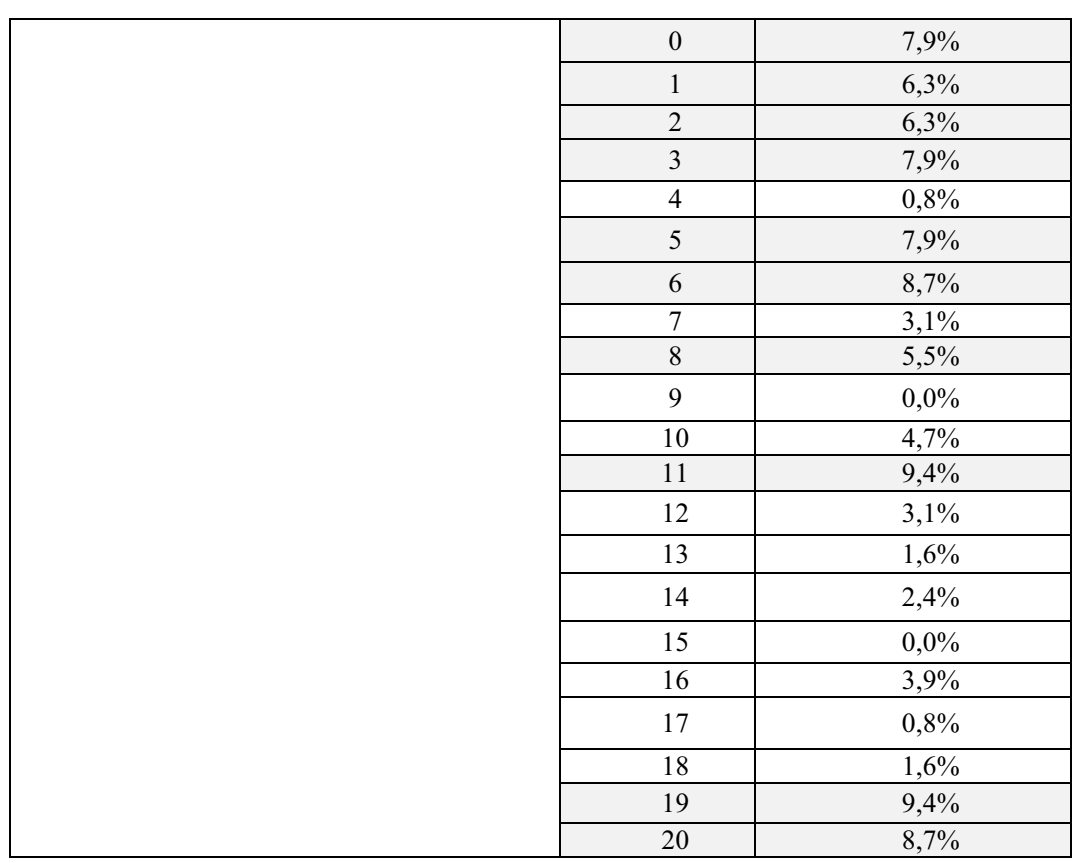

Figure 2. Part of the human body more lesioned - Shoes Industry Source: Field research

However, the left side $(26,0 \%)$ presents larger indisposition incidence when compared with the right side $(18,1 \%)$, with prominence for arm $(8,7 \%)$ and left wrist $(9,4 \%)$. One of the causes of that result is the effort that the employee should do with their left side to receive the footwear in the form and to accomplish their activity during the whole work period.

In this research it was also observed that some of the furniture possesses alive corner and doesn't have height adjustment, as well as some machines has devices out of the angle of ideal reach. Tools of manual work don't possess appropriate way of hold and the layout doesn't assist to the ergonomic principles, doing with the worker accomplishes many repetitive movements, with forced posture.

\subsection{Results of all activities}

In analyzing the data in general, one can observe that the cervical region (0), dorsal $(1,2,3)$, bowl (4), shoulders $(5,11)$ and left leg $(10)$ had higher number of complaints of injuries after the workday, as shown in Figure 3: 


\begin{tabular}{|c|c|c|c|}
\hline \multirow{19}{*}{ LEFT SIDE } & & \multirow{2}{*}{$\begin{array}{c}\text { MEMBERS } \\
0\end{array}$} & \multirow{2}{*}{$\begin{array}{c}\text { \% RECLAMATIONS } \\
9,2\end{array}$} \\
\hline & & & \\
\hline & & 1 & 8,2 \\
\hline & & 2 & 7,3 \\
\hline & & 3 & 8,1 \\
\hline & & 4 & 5,8 \\
\hline & & 5 & 5,5 \\
\hline & & 6 & 4,2 \\
\hline & & 7 & 1,6 \\
\hline & & 8 & 3,7 \\
\hline & & 9 & 2,7 \\
\hline & & 10 & 7,1 \\
\hline & & 11 & 9,0 \\
\hline & & 12 & 4,5 \\
\hline & & 13 & 2,3 \\
\hline & & 14 & 2,6 \\
\hline & & 15 & 2,4 \\
\hline & & 16 & 4,2 \\
\hline & & 17 & 2,6 \\
\hline \multicolumn{2}{|c|}{ Reclamations up to $5 \%$} & 18 & 0,5 \\
\hline \multirow{2}{*}{\multicolumn{2}{|c|}{ Reclamations besides of $5 \%$}} & 19 & 3,7 \\
\hline & & 20 & 4,8 \\
\hline
\end{tabular}

Figure 3. Part of the human body more lesioned Source: Field research

Strong discomfort suffered in the neck (9.2\%) typically occur because of incorrect positioning of devices and actuators. The inadequate conditions of machinery and of securities cause strong discomfort to workers throughout the region of the spine and shoulders, corresponding to $23.6 \%$ and $14.5 \%$ of complaints.

These coupled with the amount of small cycles, high repetition of movements, low mobility of the lower limbs cause fatigue and disease in the muscles of the legs $(10,16)$, which account for $10.4 \%$ of all reclamations.

\section{Conclusions}

With relationship to the most painful areas, it was identified that neck, backs, loin, shoulders and legs are the areas that received larger number of complaints from RTD. With relationship to the form of accomplishment of the work, the tasks accomplished seated showed more discomfort report, followed for the activities carried out in standing position.
In the sectors of transportation and of footwear production the man is the principal transformation input, therefore, they should be propitiated conditions that propitiate larger comfort to the workers, having periods of programmed stop for movement, muscular relaxation and better sanguine circulation of the body.

From the presented study it is expeted that it can supply to the managers information that make possible them to address their resources better in the attendance to the ergonomic conditions of their areas, providing the reduction of the labor liabilities for RTD.

\section{References}

[1] Anuário Estatístico da Previdência Social 2008. Ministério da Previdência Social/ Empresa de Tecnologia e Informações da Previdência Social. Brasília: MPS/DATAPREV, 2008.

[2] Anuário Estatístico de Acidentes do Trabalho - AEAT 2008. Ministério da Previdência Social/ Empresa de Tecnologia e Informações da Previdência Social. Brasília: MPS/DATAPREV, 2008. 
[3] Barbe, Mary F.; Barr, Ann E. Inflammation and the pathophysiology of work-related musculoskeletal disorders. Brain, behavior and immunity, vol. 20, p. 423-429, 2006.

[4] Bentley, T.A. The role of the New Zealand forest industry injury surveillance system in a strategic ergonomics, safety and health research programme. Applied Ergonomics, vol. 33, p. 395-403, 2002

[5] Byl, Nancy N. Aberrant learning in individuals who perform repetitive skilled hand movements: Focal hand dystonia - part 1. Journal of Bodywork and Movement Therapies, vol. 10, p. 227-247, 2006

[6] Corllet, E. N.; Manenica, I. The Effects and Measurement of Working Postures. Applied Ergonomics. 11 (01): 7-16, 1980.

[7] Couto, H. A. Doenças Osteomusculares Relacionadas com o Trabalho: Coluna e Membros Inferiores. In: MENDES, R (Org.). Patologia do trabalho. 2. ed. Rio de Janeiro: Atheneu, 2007.

[8] Dellve, Lotta et al. The impact of systematic occupational health and safety management for occupational disorders and long-term work attendance. Social Science e Medicine, vol. 67 p. 965-970, 2008 .

[9] Jones, T.; Kumar, S. Comparison of ergonomic risk assessments in a repetitive high-risk sawmill occupation: Saw-filer. International Journal of Industrial Ergonomics. Vol. 37, p. 44753, 2007.

[10]Munck-Ulfsalt, U. et al. Corporate ergonomics programme at Volvo Car Corporation. Göteborg, Sweden. Applied Ergonomics 34, p. 17-22, 2003.

[11] Niu, Shengli. Ergonomics and occupational safety and health: An ILO perspective. Applied Ergonomics, vol. 41, p. 744-753, 2010.

[12] Saksvik, P.; Quinlan, M. Regulating systematic occupational health and safety management. Comparing the Norwegian and Australian experience. Industrial Relations, vol. 58, n.1, p. 3356, 2003.

[13] Serranheira, F. et al. Lesões musculoesqueléticas (LME) e trabalho: uma associação muito freqüente. Portugal: Escola Superior Agrária de Viseu (ESAV), 2010. Disponível em: < http://www.esav.ipv.pt/sst2.pdf $>$. Acesso: 06 set. 2010.

[14] Van Galen, Gerard P. et al. Effects of a vertical keyboard design on typing performance, user comfort and muscle tension. Applied Ergonomics, vol. 38, p. 99-107, 2007.

[15] Wahlstrom, Jen. Ergonomics, musculoskeletal disorders and computer work. Occupational Medicine, vol. 55, p. 168-176, 2005 . 